\title{
First encounters with gender minority related information: results of an Internet survey
}

\author{
Aira Huttunen \\ University of Oulu \\ aira.huttunen@oulu.fi
}

The topic of this paper is how people representing gender minorities have first encountered with information concerning gender minorities. Gender minorities includes transgender, gender nonconforming, cross-dressers and intersex people. Transgender peoples' gender identities, expressions, or behaviors are not associated with their birth sex and they may be treated with hormonal or surgical procedures to make their bodies more congruent with their gender identities. The gender identity of gender nonconforming people is not binary (i.e., either male or female) and they may want partial or total transition treatments. Cross-dresser refers to people who enjoy wearing the clothing and adopting the style that is considered by society to be of other sex. Intersex refers to persons born with atypical genital or reproductive anatomy who usually identify as male or female. (Mayer et al., 2008.; Veale, Lomax, \& Clarke, 2010)

The previous studies indicate that gender minority people actively seek information related to their own gender identity (Adams \& Peirce, 2006; Pohjanen \& Kortelainen, 2016; Taylor, 2002). Besides active information seeking, people sometimes find information by chance and in unexpected places. Information about transgender phenomenon at the first time can be found serendipitously from books, television or the internet. The first encounter with the phenomenon does not necessarily provoke a full information need (Pohjanen \& Kortelainen, 2016). Austin (2003) has separated four ways of how information can be found serendipitously. These ways are:

This article is licensed under the terms of the CC BY-NC-SA 4.o -license

Persistent identifier: https://doi.org/10.23978/inf.76074 
- blind luck (chance that comes with no effort on our part);

- happy accident (chance which is due to exposure to seemingly unconnected facts and experiences);

- prepared mind (chance is perceived due to exposure to many facts related to the problem at hand); and

- individual (chance favours a particular individual as a result of the person's distinctive knowledge or interest). (Austin, 2003, pp. 71-74; Foster \& Ellis, 2014.)

\section{Methodology and results}

In this presentation we are interested of gender minorities' first encounters with information relating to their own gender identity. The data were collected using an online questionnaire survey executed by the Webropol survey tool in spring 2016. The majority of the questions in the survey were formulated based on the findings of our previous study (Pohjanen \& Kortelainen, 2016) where transgender people were interviewed about their information behaviour.

The survey was conducted by sending link to the questionnaire a total of ten Finnish LGBTI organizations and discussion forums. Sample size for analysis was 162. The respondents were from 15 to 72 years old. The mean age was 29.27 years. Gender identities are presented in table 1.

Table 1: Gender identities of the respondents.

\begin{tabular}{lrr}
\hline Gender identity & Frequency & Percent \\
\hline Transgender & 20 & 12.3 \\
(Trans)male & 54 & 33,3 \\
(Trans)female & 21 & 13,0 \\
Gender nonconforming & 45 & 2,8 \\
Cross-dresser & 3 & 1,9 \\
Intersex & 1 & 0.6 \\
Other & 18 & 1,1 \\
Total & 162 & 100,0 \\
\hline
\end{tabular}

For the respondents the most typical age to find out gender minorities are existing for the first time was between 13 to 18 ( $75,46 \%)$. Only six (4\%) of the respondents had got information under the age of 6 . Five $(3 \%)$ of the respondents had found about gender minorities at the age over 30.

First encounters with gender minority related information had happened via Internet (42), Television, movie or a document (23), school (18), friend or other close people (18), magazine (14), Human rights advocacy organisation Seta or Transgender support center (10), porn magazine (7), other person (7), book (5), 
own experience (4), therapist (2) and Prometheus-camp (1). This question about first encounters was open-ended question and respondents used terms such as "I accidently heard," "I was exposed to" and"I run into"expressing in several cases serendipitous encounters had happened. For example, blind luck had occurred in this situation:

Sain tietää ensimmäistä kertaa sukupuolivähemmistöistä, kun Marja-Sisko Aallosta uutisoitiin. [ I found about gender minorities for the first time at the time when there was news about Marja-Sisko Aalto.]

Happy accidents and blind luck may be hard to separate, but for example, when a friend or other person "comes out from closet" can be the case of a happy accident. One of the respondents describes a prepared mind, where the phenomenon exists, but is not yet connected with the own experience:

Transihmiset olivat minulle olemassa tavallaan näkökenttäni laidalla, sivulauseissa ja vitseissä. En tiennyt mistä ilmiössä oli varsinaisesti kyse. Asiallista faktatietoa löysin vasta kun etsin sitä aktiivisesti. [Transgender people were existing to me in the side of the vision in a way, in subordinate clauses and in jokes. I did not know what the phenomenon was about. Objective, fact-based information I found not until I started to seek it actively.]

Individual encounters may happen when someone has more information than the person him/herself, for example therapist or a partner. In these cases, the other person had offered information for the respondent. At the time of first encounter the respondents had mostly found out gender minority people are existing and usually the information had concerned transmale or transfemale people. After the first encountering with the information 123 ( $76 \%$ of the respondents wanted to know more about the gender minorities.

Information about gender minorities has increased during past decades, and it easier to get in touch with the information as well. Many of the first encounters with gender minority related information had happened serendipitously. Serendipitous encounters can happen because of blind luck, happy accidents, prepared mind and individual encounters. However, all encounters do not start a further information search. 


\section{References}

Adams, S. S., \& Peirce, K. (2006). Is there a transgender canon? Information seeking and use in the transgender community. Proceedings of the Annual Conference of CAIS 2006, 1-7. http: //wWw. cais-acsi.ca/ojs/index.php/cais/article/view/24

Austin, J. H. (2003). Chase, chance, and creativity: The lucky art of novelty. Cambridge, Mass.: MIT Press.

Foster, E. A., \& Ellis, D. (2014). Serendipity and its study. Journal of Documentation, 7o(6), 10151038. https://doi.org/10.1108/JD-03-2014-0053

Mayer, K. H., Bradford, J. B., Makadon, H. J., Stall, R., Goldhammer, H., \& Landers, S. (2008). Sexual and gender minority health: What we know and what needs to be done. American Journal of Public Health, 98(6), 989-995. https://doi.org/10.2105/AJPH. 2007.127811

Pohjanen, A. M., \& Kortelainen, T. A. M. (2016). Transgender information behaviour. Journal of Documentation, 72(1), 172-190. https://doi.org/10.1108/JD-04-2015-0043

Taylor, J. K. (2002). Targeting the information needs of transgender individuals. Current Studies in Librarianship, 26(1/2), 85-110.

Veale, J. F., Lomax, T., \& Clarke, D. (2010). Identity-defense model of gender-variant development. International Journal of Transgenderism, 12(3), 125-138. https://doi.org/10.1080/15532739. 2010.514217 